\title{
Reply to D. L. Peters' Comment on 'Streamflow input to Lake Athabasca, Canada" by Rasouli et al. (2013)
}

\author{
K. Rasouli ${ }^{1}$, M. A. Hernández-Henríquez ${ }^{2}$, and S. J. Déry ${ }^{2}$ \\ ${ }^{1}$ Centre for Hydrology, University of Saskatchewan, Saskatoon, Saskatchewan, Canada \\ ${ }^{2}$ Environmental Science and Engineering Program, University of Northern British Columbia, \\ Prince George, British Columbia, Canada
}

Correspondence to: S. J. Déry (sdery@unbc.ca)

Received: 8 October 2014 - Published in Hydrol. Earth Syst. Sci. Discuss.: 4 November 2014 Revised: 29 January 2015 - Accepted: 10 February 2015 - Published: 6 March 2015

\begin{abstract}
This paper provides a reply to a comment from Peters (2014) on our recent effort focused on evaluating changes in streamflow input to Lake Athabasca, Canada. Lake Athabasca experienced a $21.2 \%$ decline in streamflow input between 1960 and 2010 that has led to a marked decline in its water levels in recent decades. A reassessment of trends in naturalized Lake Athabasca water levels shows insignificant changes from our previous findings reported in Rasouli et al. (2013), and hence our previous conclusions remain unchanged. The reply closes with recommendations for future research to minimize uncertainties in historical assessments of trends in Lake Athabasca water levels and to better project its future water levels driven by climate change and anthropogenic activities in the Athabasca Lake basin.
\end{abstract}

\section{Reply}

We thank Peters (2014; hereafter P14) for his comment on our recent article focusing on streamflow input to Canada's Lake Athabasca (Rasouli et al., 2013; hereafter R13). This reply provides us with an opportunity to respond to the concerns raised in P14, to clarify the objectives of R13, to update and reaffirm our previously published results, to elaborate on their possible implications on Lake Athabasca water levels, and to propose recommendations for future work. To frame our response, we first outline briefly the two main issues of concern expressed in P14. Issue 1: P14 raises uncertainties on R13's reported trend in the (partially) naturalized levels of Lake Athabasca that omitted its hydraulic connectivity to the Peace-Athabasca Delta (PAD), a $6 \%$ streamflow diver- sion from the Athabasca River towards Mamawi Lake downstream of the McMurray hydrometric gauge, a geodetic reference change in 2010 for the hydrometric station near Crackingstone Point, the filling of the Williston Reservoir on the upper Peace River from 1968 to 1971, regulation of the Peace River for hydroelectricity operation between 1972 and 1975, and the occurrence of ice-jam floods in 1974, 1996 and 1997 that obstructed the northward drainage from Lake Athabasca. Issue 2: the simple linear extrapolation of the 1960-2010 Lake Athabasca levels to 2100 provides misleading information on their potential future fate. We address these points after revisiting the principal objective and conclusions of R13.

\subsection{Past streamflow input to Lake Athabasca}

First, we emphasize that the primary objective of R13 was to "assess the changes in streamflow input to Lake Athabasca and to compare these results with recent sediment core studies in the area." This goal was achieved using an observationbased streamflow data set for eight rivers draining into Lake Athabasca over 1960-2010. The results of that study reveal a $7.22 \mathrm{~km}^{3}$ or $21.2 \%$ decline in total Lake Athabasca inflows over the 51-year period of interest. This includes a $37.9 \%$ decline in streamflow for the main stem Athabasca River below McMurray (location of the furthest downstream hydrometric gauge on the river with publicly accessible hydrometric data), with substantially lesser reductions in other neighbouring rivers draining into the lake. These findings are consistent with those of other recent studies that have investigated Athabasca River streamflow trends (e.g., Schindler and Donahue, 2006; Peters et al., 2013; Bawden et al., 2014; Rood et al., 2015). Thus, our finding of a general decline 
in streamflow input to Lake Athabasca in recent decades is supported by other studies, and R13's principal conclusions remain valid.

\subsection{Past Lake Athabasca levels}

The first main point of concern expressed in P14 is the potential impact of streamflow changes on Lake Athabasca water levels. We agree that an accurate analysis of observed trends in Lake Athabasca levels requires consideration of three factors neglected in R13: (1) hydrological interactions between the PAD and Lake Athabasca; (2) the geodetic reference change at the hydrometric gauge near Crackingstone Point in 2010; and (3) the filling of the Williston Reservoir behind the WAC Bennett Dam from 1968 to 1971. We update here the analyses presented in R13 to further naturalize the Lake Athabasca levels in consideration of these issues, but demonstrate that this leads to insignificant changes to our previously published results and conclusions. Prior to that, however, we emphasize that R13 addresses this topic as a point of discussion, rather than as a part of their results, and that it is not a primary objective of that study. As such, the lake level changes over 1960-2010 owing to streamflow input declines reported by R13 are of first order only. A comprehensive assessment of changes in the levels of Lake Athabasca clearly requires a more rigorous approach, including an analysis of vertical (e.g., precipitation, evaporation, infiltration, etc.) and horizontal (e.g., total streamflow input and output, groundwater exchanges, etc.) water fluxes to the lake in addition to anthropogenic influences (e.g., bitumen extraction). This should also include consideration of flows (i.e., 6\%) diverted from the Athabasca River towards Mamawi Lake (which would strengthen the declining trends of streamflow input to Lake Athabasca) and the hydraulic connectivity of Lake Claire, Mamawi Lake, and the remainder of the PAD with Lake Athabasca (P14). Such an analysis was clearly beyond the scope and objectives of R13's study. Nevertheless, we note that our (partially naturalized) lake level trend analysis closely matches the corresponding value obtained through streamflow input changes, providing confidence in the reliability of those initial results (consult R13).

Following P14's suggestion, and for completeness, we update and reassess our trend estimates of the 1960-2010 levels of Lake Athabasca near Crackingstone Point (station ID 07MC003) using the Mann-Kendall test (MKT; Mann, 1945; Kendall, 1975; Déry et al., 2005). Here, the lake levels are naturalized to consider the 2010 shift in the Crackingstone Point benchmark elevation and artificial modifications during the filling of the Williston Reservoir in British Columbia and regulation of the Peace River for hydropower development and generation, in addition to the obstruction of Lake Athabasca drainage northward caused by occasional ice-jam flood events in the lower Peace River and construction of weirs on the channels controlling the lake outflow (as already considered in R13). High stage on the lower Peace
Table 1. Linear trends $\left(\mathrm{m} \mathrm{yr}^{-1}\right)$ of the naturalized lake levels at two locations on Lake Athabasca over 1960-2010 with $p$ values given in parentheses (JJA: June-August, SON: September-November, DJF: December-February, MAM: March-May).

\begin{tabular}{lcc}
\hline Period & Crackingstone Point & Fort Chipewyan \\
\hline Annual & $-0.016(0.02)$ & $-0.016(0.02)$ \\
JJA & $-0.016(0.01)$ & $-0.016(0.02)$ \\
SON & $-0.021(0.01)$ & $-0.021(0.01)$ \\
DJF & $-0.018(0.01)$ & $-0.017(0.01)$ \\
MAM & $-0.009(0.13)$ & $-0.009(0.12)$ \\
July & $-0.016(0.02)$ & $-0.014(0.03)$ \\
\hline
\end{tabular}

River can affect the levels of Lake Athabasca through hydraulic damming that can reverse the direction of lake outflows (P14). As such, the construction of the WAC Bennett Dam on the upper Peace River and the ensuing water retention behind it in the Williston Reservoir over 1968-1971 requires special attention owing to its possible impacts on Lake Athabasca levels. This is therefore considered in our updated analyses, in addition to the construction of weirs in 1975 and 1976 on the outflow channels draining Lake Athabasca and the 2010 benchmark elevation change of $0.709 \mathrm{~m}$ at Crackingstone Point.

P14 expresses concerns on the impacts of the chosen time periods for R13's trend analyses that included high flows in the early $1960 \mathrm{~s}$. R13 selected three common study periods each, ending in 2010, with the longest period starting in 1960 , the year after which most of the hydrometric gauges in this system became active. These time series are selected to conduct systematic trend analyses based largely on observed data with only limited use of reconstructed data and to avoid the biases that might be introduced by high or low flows at the beginning of the time series. Adding data from a few years prior to 1960 and after 2010 changes slightly the trend magnitudes; however, these results do not alter the conclusions of R13, as the MKT is insensitive to outliers in the lake level time series (Wilks, 2011). For instance, the 1958-2013 mean annual lake level near Crackingstone Point exhibits a statistically significant decreasing trend of $0.014 \mathrm{~m} \mathrm{yr}^{-1}(p=0.01)$ that is slightly less than the $0.016 \mathrm{~m} \mathrm{yr}^{-1}$ decline for 1960 2010 (Table 1). Another issue P14 raises is the inconsistency and scale mismatch between the mean annual lake level trends over 1960-2010 obtained by R13 and mean July lake levels over 1942-1967 found by Muzik (1991). Adding an analysis for July lake levels reveals nearly identical change rates for the annual and July time series of water levels, providing support for R13's findings covering 1942-2010. The 1960-2010 decreasing lake levels in July when peak values are typically reached near Crackingstone Point (see Table 1), in addition to the findings of Muzik (1991) traced back to 1942, confirm that mean July water levels have fallen $1.59 \mathrm{~m}$ over the 1942 to 2010 period, near the value reported in R13. 

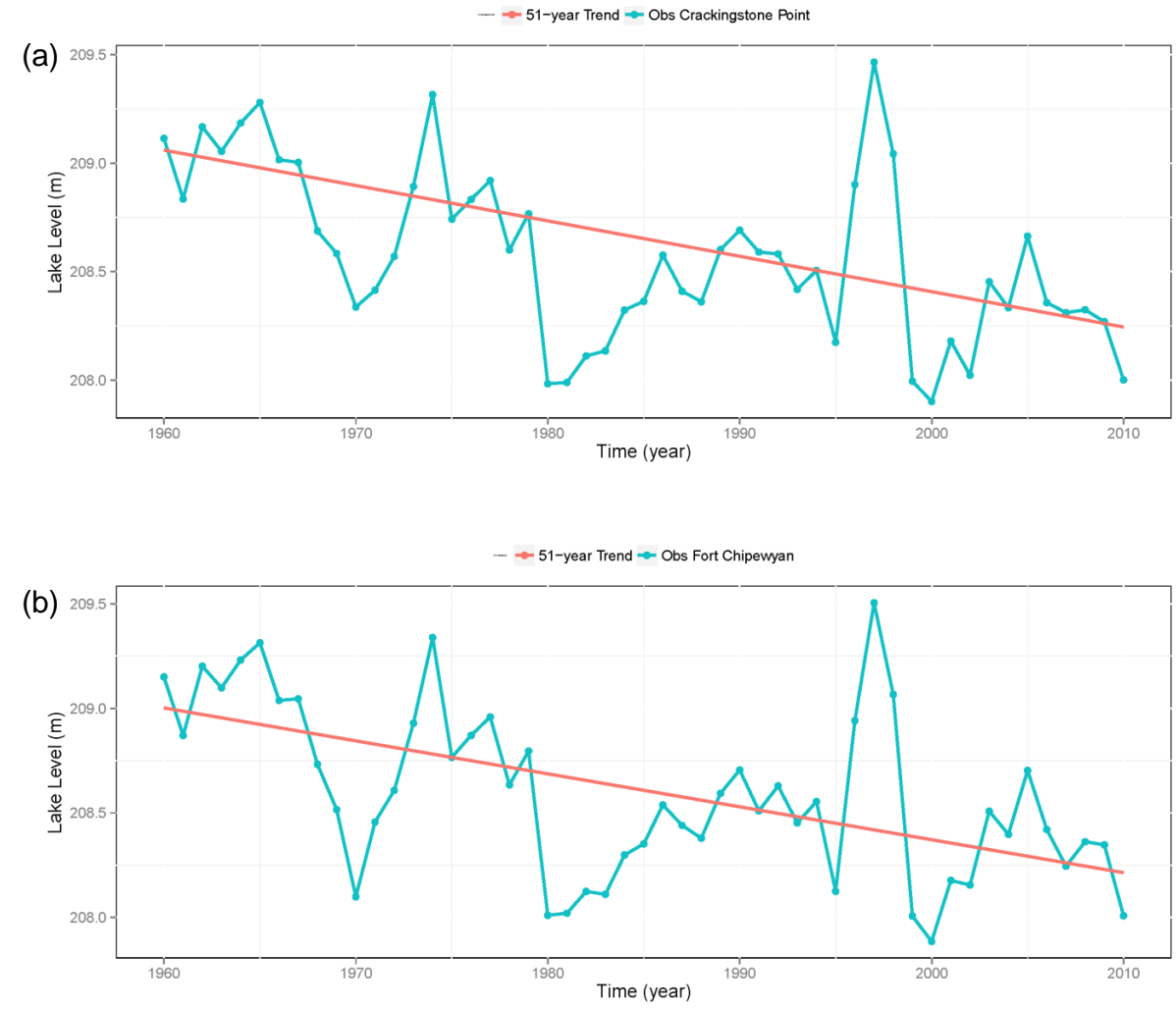

Figure 1. Time series and linear trends of naturalized, mean annual level of Lake Athabasca observed (Obs) (a) near Crackingstone Point and (b) at Fort Chipewyan, 1960-2010.

Next, the Lake Athabasca level data at Fort Chipewyan (station ID 07MD001) are added for supplemental analyses of annual, seasonal, and July trends in lake levels for comparison with the results near Crackingstone Point over 1960-2010 (Fig. 1). The two stations exhibit similar and statistically significant $(p<0.05)$ declining trends in mean annual and seasonal lake levels except during spring (MarchMay; see Table 1). The magnitude and significance of trends in naturalized Lake Athabasca levels are nearly identical whether assessed with hydrometric data from near Crackingstone Point or at Fort Chipewyan, with the correlation coefficient between the two time series of annual lake level attaining $0.99(p=0)$ over 1960-2010. Strong declining trends from 1971 to 2010 in fall and winter (September to February) suggest that the high lake levels in the early 1960s are not a significant reason for recent declining lake level trends (not shown). If high lake levels in the early 1960s are leading to the declining trends, then high flows in 1997 and 1998 are moderating the declining trends. Removing the high lake levels in the late 1990s from the time series can result in even stronger declining trends. The updated results presented here demonstrate that adjusting the 2010 lake level for the change in datum reference and for naturalizing the lake levels during the filling of the Williston Reservoir in the upstream portion of the Peace River does not affect in any significant manner the findings and conclusions of R13.

\subsection{Future Lake Athabasca levels}

P14 also has reservations about R13's linear extrapolation of the 1960-2010 trend in the (partially naturalized) Lake Athabasca levels to 2100 in the context of past hydrological variability. R13's extrapolation yields a possible decline of $2-3 \mathrm{~m}$ in Lake Athabasca water levels by 2100 , values within the range observed in the mid-Holocene period as inferred from a sediment core retrieved within a pond in close proximity to the lake (Wolfe et al., 2011). We believe that lake levels were higher during the Little Ice Age (LIA) period when water was abundant and western Canada was developed (Wolfe et al., 2011) as a result of the prior glacier expansion period. However, unlike the LIA period when water was plentiful, we argue that much drier times are ahead, and that future water availability is likely to resemble that of the mid-Holocene period due to the following reasons: (1) global air temperatures are expected to continue increasing significantly, especially at northern latitudes (i.e., over $5{ }^{\circ} \mathrm{C}$; Nogués-Bravo et al., 2007); (2) there are no signs of a second ice age occurring before 2100 to provide increases in available water resources; and (3) water extraction for oil exploitation will continue and amplify in the PAD re- 
gion and ongoing power generation from the rivers feeding Lake Athabasca during the twenty-first century. P14 mentions the higher levels of Lake Athabasca during the LIA inferred from those seen in the same sediment core, which highlights the high variability in lake levels. However, given the above-mentioned reasons and the declining streamflow input to Lake Athabasca reported in R13, and hence its level, it seemed irrelevant to bring this matter into our discussion.

We concur that a detailed analysis of future climatic conditions and hydraulic controls would allow better projections of twenty-first century Lake Athabasca levels, but argue that forthcoming anthropogenic activities in the basin must also be taken into consideration. Thus, a more rigourous approach to better constrain estimates of potential future levels of Lake Athabasca is to employ global climate models (GCMs) or regional climate models (RCMs) driven by future greenhouse gas emissions scenarios. For instance, Kerkhoven and Gan (2011) apply seven GCMs forced by Special Report on Emissions Scenarios (SRES) A1FI, A2, B1, and B2 to investigate the twenty-first century sensitivity of the hydrology of two major watersheds of western Canada, the Fraser and Athabasca River basins. Across all four scenarios and seven GCMs, they find a $21.1 \%$ decline in the mean annual flows of the Athabasca River from 2070 to 2099 with respect to the baseline period 1961-1990. Such a decline, if realized, would double the reduction in Lake Athabasca levels observed over 1960-2010 from changes in streamflow input only.

The impacts of future climate change on streamflow input to Lake Athabasca assessed with climate models do not consider anthropogenic activities such as water withdrawals for human consumption, irrigation, and bitumen extraction. The hydrometric gauge on the main stem Athabasca River at McMurray remains upstream of the major Alberta oil sands deposits and does not reflect water withdrawals related to bitumen extraction. Pavelsky and Smith (2008) report that current water extraction related to oil production in the Alberta oil sands will rise and triple from $0.54 \mathrm{~km}^{3} \mathrm{yr}^{-1}$ in 2006 to $1.61 \mathrm{~km}^{3} \mathrm{yr}^{-1}$ in 2015 . Since most of that water does not return to the Athabasca River, it could lead to a further $0.21 \mathrm{~m}$ decline in lake levels in 2015, with the potential for greater impacts later in the century if bitumen extraction continues to intensify (e.g., Jordaan et al., 2009).

\section{Conclusions and recommendations}

This reply to a comment from P14 confirms our previous findings and conclusions on the magnitude of streamflow input declines in the Lake Athabasca drainage with potential impacts on its level over 1960-2010. R13 reported a $7.22 \mathrm{~km}^{3}$ or $21.2 \%$ decline in total streamflow input to Lake Athabasca over 51 years that alone could lead to a $0.95 \mathrm{~m}$ reduction of its levels. This result was entirely consistent with the observed decline of $0.82 \mathrm{~m}$ in Lake Athabasca lev- els measured near Crackingstone Point over the same study period. Naturalizing the time series of Lake Athabasca levels for consideration of a geodetic reference change in 2010 near Crackingstone Point and for the filling of the Williston Reservoir on the upper Peace River in 1968-1971 does not alter our previous estimates of potential lake level changes. Furthermore, a comparison of the trends in the naturalized levels of Lake Athabasca recorded near Crackingstone Point to those at Fort Chipewyan reveals nearly identical results for 1960 to 2010. Thus, despite the concerns expressed in P14, the conclusions obtained by R13 on Lake Athabasca streamflow input and levels remain entirely valid.

The proliferation of recent work on the hydrology of the Lake Athabasca drainage demonstrates the keen interest that exists in better understanding this economically and ecologically important basin. We therefore end this reply with the following recommendations for future research efforts:

1. A comprehensive water budget for Lake Athabasca with consideration of all major freshwater fluxes over a historical period remains a priority for future research. This could include a combination of observed and simulated water fluxes to develop a century-scale water budget for Lake Athabasca with impacts on its water levels. Remote sensing products could also supplement observational and modelling data sets, either through optical data to estimate changes in surface water area (e.g., Pavelsky and Smith, 2008) or gravimetric data for total volumetric changes in basin-scale water storage (e.g., Sheffield et al., 2009).

2. The construction of the large Site $\mathrm{C}$ dam by BC Hydro on the Peace River near Fort St. John, BC, was recently approved in December 2014, which may lead to further alterations on the hydrology of the Lake Athabasca system. Future work should therefore assess the possible hydrological impacts of the planned Site C dam, in addition to the possible consequences imposed on this system (e.g., recharge of the PAD).

3. Augmenting the network of hydrometric gauges along rivers draining into Lake Athabasca, especially on the main stem Athabasca River downstream from the Alberta oil sands operations, is of great priority and should be implemented immediately. This is particularly important to assess the rapidly intensifying demands for freshwater (sourced mainly from the Athabasca River itself) used in the extraction of bitumen from the oil sands operations in the region.

4. To extend back in time the instrumental-era records of the Lake Athabasca basin hydrology, additional proxy data throughout the basin should be collected, compared, and synthesized. This could include samples of sediment cores (e.g., Wolfe et al., 2008, 2011) and tree rings (Sauchyn et al., 2011). This will put into perspective the historical variability in the hydrological regime 
of this drainage basin and provide insights into its current state and future fate. In addition, trend analysis of historical hydroclimatic records can only provide nearfuture hydrological prospects of the Lake Athabasca system, and thus climate models are needed for longterm projections.

5. Projecting future inflows to Lake Athabasca with potential impacts to its levels necessitates high-resolution output from GCMs or RCMs to drive state-of-the-art hydrological models (e.g., the Variable Infiltration Capacity model; Liang et al., 1994; Kang et al., 2014). These climate model simulations require full consideration of anthropogenic influences (i.e., land cover/use changes, flow regulation and retention, and water extraction), climate variability (i.e., impacts of the phase change of large-scale teleconnections such as El NiñoSouthern Oscillation (ENSO) and Pacific Decadal Oscillation (PDO) on lake inflows), in addition to a range of climate change scenarios, to assess the potential future freshwater supply in the Lake Athabasca drainage. These climate simulations should also assess the diminishing contribution of glacier melt to runoff generation in the headwaters of the Athabasca River (Marshall et al., 2011). This will lead to improved knowledge of the potential future variability and extremes in Lake Athabasca levels, allowing for better management of freshwater resources, policy development and adaptation strategies in northern Canada.

6. Exchanges of information from holders of traditional knowledge and that derived from western science should be undertaken to obtain a broader perspective on observed changes in the Lake Athabasca drainage. Merging these two lines of knowledge has been shown to provide corroborating evidence on the impacts of climate change on the environment, including water resources (e.g., Sanderson et al., 2015). We thus encourage a continued dialogue between First Nations communities living in and near the watersheds flowing into Lake Athabasca and western scientists to expand our knowledge of this important system in a period of accelerating environmental and climate changes.

Acknowledgements. Funding provided by the government of Canada's Canada Research Chair (CRC) program and an NSERC Discovery Grant awarded to S. J. Déry. Sincere thanks also to Stewart Rood (University of Lethbridge) and David Sauchyn (University of Regina) for their constructive comments that led to an improved paper.

Edited by: A. Ghadouani

\section{References}

Bawden, A. J., Linton, H. C., Burn, D. H., and Prowse, T. D.: A spatiotemporal analysis of hydrological trends and variability in the Athabasca River region, Canada, J. Hydrol., 509, 333-342, 2014.

Déry, S. J., Stieglitz, M., McKenna, E. C., and Wood, E. F.: Characteristics and trends of river discharge into Hudson, James, and Ungava Bays, 1964-2000, J. Climate, 18, 2540-2557, 2005.

Jordaan, S. M., Keith, D. W., and Stelfox, B.: Quantifying land use of oil sands production: A life cycle perspective, Environ. Res. Lett., 4, 024004, doi:10.1088/1748-9326/4/2/024004, 2009.

Kang, D. H., Shi, X., Gao, H., and Déry, S. J.: On the changing contribution of snow to the hydrology of the Fraser River Basin, Canada, J. Hydrometeorol., 15, 1344-1365, 2014.

Kendall, M. G.: Rank Correlation Methods, Charles Griffin, London, 160 pp., 1975.

Kerkhoven, E. and Gan, T. Y.: Differences and sensitivities in potential hydrologic impact of climate change to regional-scale Athabasca and Fraser River basins of the leeward and windward sides of the Canadian Rocky Mountains respectively, Climatic Change, 106, 583-607, doi:10.1007/s10584-010-9958-7, 2011.

Liang, X., Lettenmaier, D. P., Wood, E. F., and Burges, S. J.: A simple hydrologically based model of land-surface water and energy fluxes for general-circulation models, J. Geophys. Res., 99, 14415-14428, 1994.

Mann, H. B.: Nonparametric tests against trend, Econometrica, 13, 245-259, 1945.

Marshall, S. J., White, E. C., Demuth, M. N., Bolch, T., Wheate, R., Menounos, B., Beedle, M. J., and Shea, J. M.: Glacier water resources on the eastern slopes of the Canadian Rocky Mountains, Can. Water Resour. J., 36, 109-134, 2011.

Muzik, I.: Hydrology of Lake Athabasca, Hydrology of Natural and Manmade Lakes, Proc. of the Vienna Symposium, August 1991, IAHS-AISH Publ., 226, 13-22, 1991.

Nogués-Bravo, D., Araújo, M. B., Errea, M. P., and Martinez-Rica, J. P.: Exposure of global mountain systems to climate warming during the 21st Century, Global Environ. Change, 17, 420-428, 2007.

Pavelsky, T. M. and Smith, L. C.: Remote sensing of hydrologic recharge in the Peace-Athabasca Delta, Canada, Geophys. Res. Lett., 35, L08403, doi:10.1029/2008GL033268, 2008.

Peters, D. L.: Comment on "Streamflow input to Lake Athabasca, Canada" by Rasouli et al. (2013), Hydrol. Earth Syst. Sci., 18, 3615-3621, doi:10.5194/hess-18-3615-2014, 2014.

Peters, D. L., Atkinson, D., Monk, W. A., Tenenbaum, D. E., and Baird, D. J.: A multi-scale hydroclimatic analysis of runoff generation in the Athabasca River, western Canada, Hydrol. Process., 27, 1915-1934, doi:10.1002/hyp.9699, 2013.

Rasouli, K., Hernández-Henríquez, M. A., and Déry, S. J.: Streamflow input to Lake Athabasca, Canada, Hydrol. Earth Syst. Sci., 17, 1681-1691, doi:10.5194/hess-17-1681-2013, 2013.

Rood, S. B., Stupple, G. W., and Gill, K. M.: Century-long records reveal slight, ecoregionlocalized changes in Athabasca River flows, Hydrol. Process., 29, 805-816, doi:10.1002/hyp.10194, 2015.

Sanderson, D., Picketts, I. M., Déry, S. J., Fell, B., Baker, S., Lee-Johnson, E., and Auger, M.: Climate change and water at Stellat'en First Nation, British Columbia, Canada: Insights 
from western science and traditional knowledge, Can. Geogr., doi:10.1111/cag. 12142, in press, 2015.

Sauchyn, D. J., Vanstone, J., and Perez-Valdivia, C.: Modes and forcing of hydroclimatic variability in the Upper North Saskatchewan River Basin since 1063, Can. Water. Resour. J., 36, 205-217, 2011.

Schindler, D. W. and Donahue, W. F.: An impending water crisis in Canada's western prairie provinces, P. Natl. Acad. Sci., 103, 7210-7216, 2006.

Sheffield, J., Ferguson, C. R., Troy, T. J., Wood, E. F., and McCabe, M. F.: Closing the terrestrial water budget from satellite remote sensing, Geophys. Res. Lett., 36, L07403, doi:10.1029/2009GL037338, 2009.
Wilks, D. S.: Statistical Methods in Atmospheric Sciences, 3rd Edn., Academic Press, Amsterdam, 676 pp., 2011.

Wolfe, B. B., Hall, R. I., Edwards, T. W. D., Jarvis, S. R., Niloshini Sinnatamby, R., Yi, Y., and Johnston, J. W.: Climate-driven shifts in quantity and seasonality of river discharge over the past 1000 years from the hydrogeographic apex of North America, Geophys. Res. Lett., 35, L24402, doi:10.1029/2008GL036125, 2008.

Wolfe, B. B., Edwards, T. W. D., Hall, R. I., and Johnston, J. W.: A 5200-year record of freshwater availability for regions in western North America fed by high-elevation runoff, Geophys. Res. Lett., 38, L11404, doi:10.1029/2011GL047599, 2011. 